Journal

of Geography,

Politics and Society

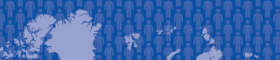

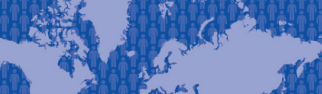

S

,

antor dy

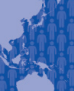

An

\section{Journal of Geography, Politics and Society}

$2017,7(4), 46-52$

DOI 10.4467/24512249JG.17.037.7637

\title{
FOREIGN DIRECT INVESTMENT IN ARMENIA
}

\section{Julia Kaczmarek-Khubnaia}

Institute of Socio-Economic Geography and Spatial Management, Adam Mickiewicz University, Krygowskiego 10, 61-680 Poznań, Poland, e-mail: khubnaia@amu.edu.pl

\section{Citation}

Kaczmarek-Khubnaia J., 2017, Foreign Direct Investment in Armenia, Journal of Geography, Politics and Society, 7(4), 46-52.

\begin{abstract}
After the fall of the Soviet Union and regaining its independence, Armenia has begun a process of systemic transformation. The level and pace of socio-economic development has been influenced by internal situation as well as by country's geopolitical position and its relations with foreign partners. The purpose of this article is to present general characteristics of foreign direct investment that has been present in Armenia since the 1990s. The author describes several key factors shaping the volume, geographical, proprietary and sectoral structure of the FDI inflows. A special attention is given to the influence of the Russian Federation on the Armenian economy.
\end{abstract}

\section{Key words}

Foreign Direct Investment, Armenia, post-Soviet region.

Received: 07 May 2017 Accepted: 06 June 2017 Published: 29 December 2017

\section{Introduction}

The level and pace of socio-economic development in the post-Soviet countries has been determined by ongoing transformation processes in terms of internal policy framework, economic goals, desired position on the geopolitical area and preferred direction of a foreign partnership development.

The collapse of the Soviet Union, one of the most powerful political powers of the 20th century, led to legislative chaos, increased unemployment, social impoverishment, widespread corruption and numerous domestic conflicts. However, it is also regarded as a crucial event in the modern history of the post-Soviet states that, together with their sovereignty, have also gained an opportunity to reorient their global political and economic relations.

The Caucasus region is considered a strategic area that has recently became a focus of attention of western observers. Its unique geographical location has led it to become a main transit route of energy resources (gas, oil). This, combined with an ongoing conflict of interests between the world's economic leaders: United States, European Union, Iran, Turkey, and the Russian Federation (the latter referring to the countries of South Caucasus as 'near abroad' that should remain in its sphere of influence), has resulted in the region becoming an area of political and economic disputes between countries aspiring to control the region. The Experts in the area of geopolitics, internal situation and a position of a given 
region on the international stage, refer to this phenomenon as 'The New Great Game' (Cohen, 1996; Iwańczuk, 2008; Gołaś, 2011).

Just like neighbouring Azerbaijan and Georgia, Armenia, together with its independence, has been given a chance to reinvent itself as a fully democratic state and to gradually eliminate the negative effects of the collapse of the Soviet Union. However, despite of many opportunities for establishing new economic and political relations, the country has remained in Russian sphere of influence, unequivocally recognizing the Russian Federation as its main political ally and key economic partner.

The purpose of this article is to present a general description of illustrate a general trend in foreign direct investment (FDI) in Armenia between 19902016. In addition to the analysis of statistical data describing the character of foreign direct investments (size, geographic and sectoral structure), the author discusses significant factors affecting FDI flows, internal situation in the analysed country, its current international position and a degree of economic dependence from the Russian Federation. The study is based on data published by Armenian Statistical Service of Republic of Armenia (ARMSTAT) and by the United Nations Conference on Trade and Development (UNCTADSTAT).

\section{Selected factors affecting the foreign direct investment process in Armenia}

Geopolitical position and historical determinants resulting from over 70 years of membership in the Soviet Union, make it necessary to consider specific FDI characteristics that affect its shape, size and structure. Researchers analysing the subject of FDI in transformation countries, identified three main factors influencing the shape and size of these investments (Bojar, 2001):

1. International organisations' membership (especially the possibility of joining the European Union).

2. The state of system transformation process (including the level of investment risk).

3. State policy encouraging FDI inflows, and investment incentives.

The most important international organisations joined by Armenia after regaining its independence are: The Commonwealth of Independent States (CIS) (1991), The United Nations (UN) (1992), The Black Sea Economic Cooperation (BSEC) (1992), The Council of Europe (COE) (2001), The Eurasian Economic Union
(EAEU) (2015) ${ }^{1}$. In spite of initial pro-European aspirations of Armenia (starting accession negotiations in 2010 and joining the Eastern Partnership (EaP)), president Serzh Sargsyan has decided against of signing the association agreement (the EaP summit, November 2013), thereby effectively stopping the integration process. The country is currently strengthening its alliance with the Russian Federation, as demonstrated by its accession to the EAEU, establishment of Russian military bases in Armenia (e.g. Gyumri), or opposing the UN resolution condemning the Crimea referendum of 2014. In one of the studies concerning the attitudes of Armenian citizens toward other countries (Caucasus Barometer, 2013), 84\% of respondents were of an opinion that the Russian Federation is one of Armenia's closest friends (Sadowski, 2013; Loda, 2017).

Another important determinant of the FDI inflow to Armenia is the state of system transformation. Since the 1990s, the country has carried out a series of reforms concerning among others, economic liberalisation and business environment. The process had undoubtedly been hindered by outbreak of war in Nagorno-Karabakh, one day before the collapse of the Soviet Union. A tense situation resulting from economic isolation caused by Azerbaijan and Turkey closing their borders and putting a trade ban on Armenia, has led to an emergence of a so-called 'conflict economy'. The difficult socio-economic situation persists to this day. The ever more powerful oligarchy based political system makes it impossible to carry out any comprehensive structural reforms. Deepening poverty, social polarisation, corruption and increase in food and energy prices have resulted in growing dissatisfaction and, which follows, more Armenians taking to the streets to protest ${ }^{2}$ (OdlingSmee, 2011; Jaroszewicz, 2017; Armenia ..., 2016).

The current state of the country's political and economic transformation is illustrated by the Bertelsmann Transformation Index (BTI) ${ }^{3}$, developed by the Bertelsmann Foundation (Bertelsmann Stiftung) (Table 1). In December 2015, indicator for Armenia was at $5.56^{4}$, which meant that the country had

\footnotetext{
1 All the relevant information concerning Armenia's membership in international organisations can be found on website of the Armenian Ministry of Foreign Affairs.

2 The internationally most well-known protest is the Electro Maidan, also known as Armenian Majdan. The main reason for the protest, was an increase in electricity prices (Falkowski, 2015).

3 The Bertelsmann Stiftung's Transformation Index (BTI) analyses and evaluates the quality of democracy, a market economy and political management in 129 developing and transition countries.

4 The index value is represented on the scale from 1 to 10 .
} 
Tab. 1. The state of Armenia's political and economic transformation process as per 2015 (BTI)

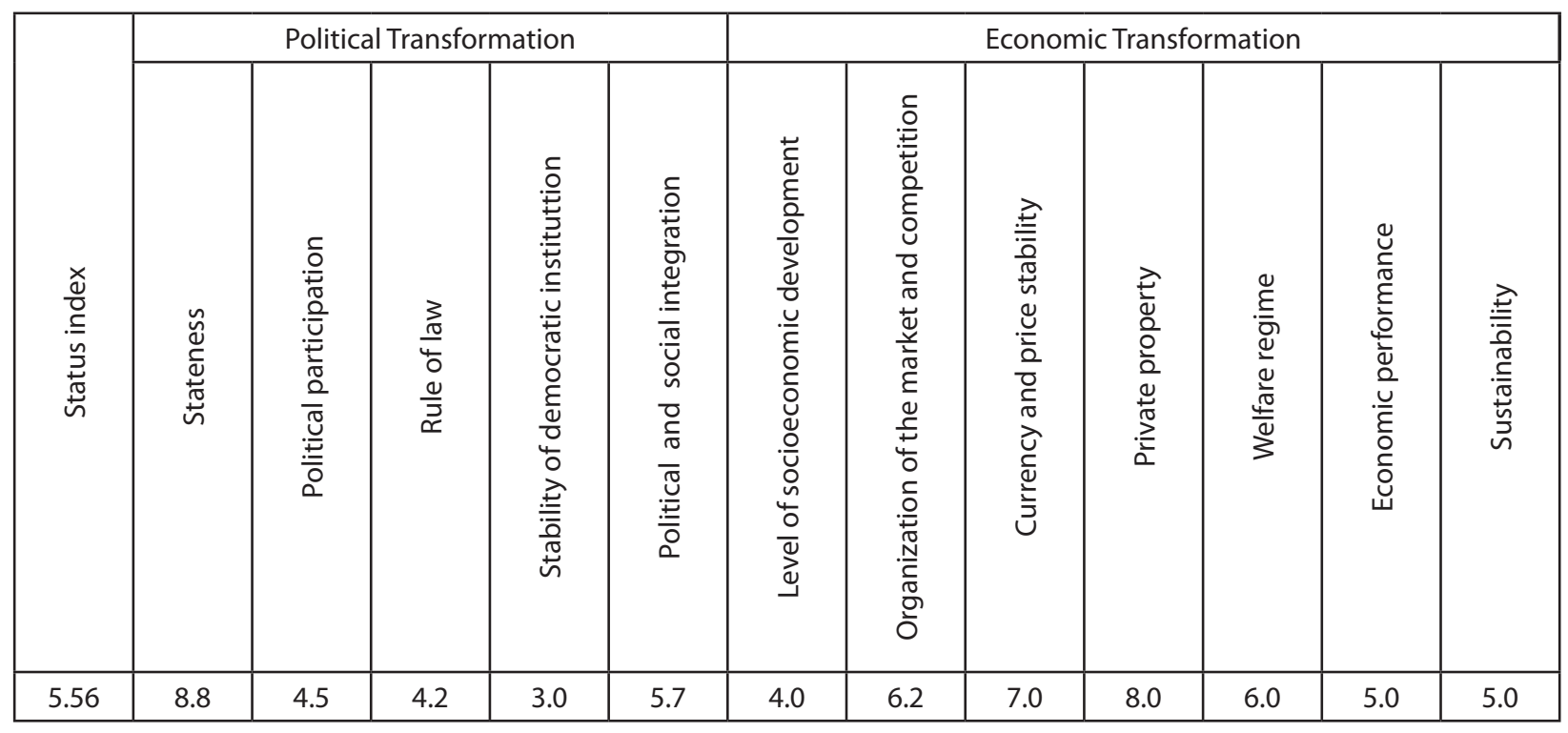

Source: own elaboration based on the Bertelsmann Transformation Index, Transformation..., 2016.

placed as 64th in the ranking of developing and transition countries (for comparison: Georgia was placed as 45th and Russia as 81st). From 13 analysed components, indicators for political stability (8.8) and private property (8.0) reached highest values while indicators for the stability of democratic institutions (3.0) and level of socio-economic development (4.0) were at the lower side of the spectrum. The data published by the BTI confirm the earlier mentioned socio-economic problems of Armenia.

The last factor determining the inflow of foreign direct investment to countries undergoing a transformation processes is the state policy encouraging FDI inflows, and investment incentives.

As far as the FDI is concerned, Armenia has declared an 'open door' investment policy towards the countries with which they are linked by 'the most favoured nation clause ${ }^{\prime 5}$. The law is defined is the 1994 "On Foreign Investment" ( $Z z$ Optikpp Onuptiplnju utipnpnufitiph Uuuhi, 1994) and in the Investment Policy of Armenia. Support for this type of investment is one of the key objectives of Armenian economic policy. Some of the main incentives introduced to attract new investors include:

1. Establishment of Free Economic Zones.

2. The law allowing a company registered by a foreigner in Armenia to buy land.

3. No sector-specific or geographic restrictions on investment.

\footnotetext{
5 Information on Armenian investment policies and the country's investment incentives are available on the websites of the Ministry of Foreign Affairs of Armenia and Invest in Armenia. Global SPC.
}

4. A possibility, for a foreign investor, to own a $100 \%$ of any given company.

5. In case of any changes in legislation, foreign investors can choose which law to use for up to 20 years.

\section{Characteristics of Foreign Direct Investment in Armenia}

When analysing statistical data concerning foreign direct investment, the author has referred to primary index of inward flows which indicates the amount of funds flowing into the country in the form of FDI (Fig. 1) ${ }^{6}$.

A year after Armenia had regained its independence, the value of funds invested by foreign partners in its economy amounted to only 2 million USD. This situation can be seen as a result of market instability (including a high level of investment risk) in the first half of the 1990s, caused by systemic transformation, economic crisis and an ongoing (since 1988) armed conflict in Nagorno-Karabakh. Since 1994, the authorities had introduced a number of important reforms regarding FDI inflow ${ }^{7}$, which re-

\footnotetext{
6 If no other source has been reported, the statistical analysis is based on data found in yearly reports of the ARMSTAT.

7 The first notable increase in the FDI value, after regaining the independence, was observed in 1998 (232 million USD). Among the most important foreign investments in Armenia at the end of the 1990s were: the takeover of the Armenian telecommunication market by a Greek company GTE, the acquisition of the Yerevan Brandy Company (YBC) by Pernod Ricard, and the procurement of the Armenian Diamond Company by Furfono (Bartlett, 2000).
} 


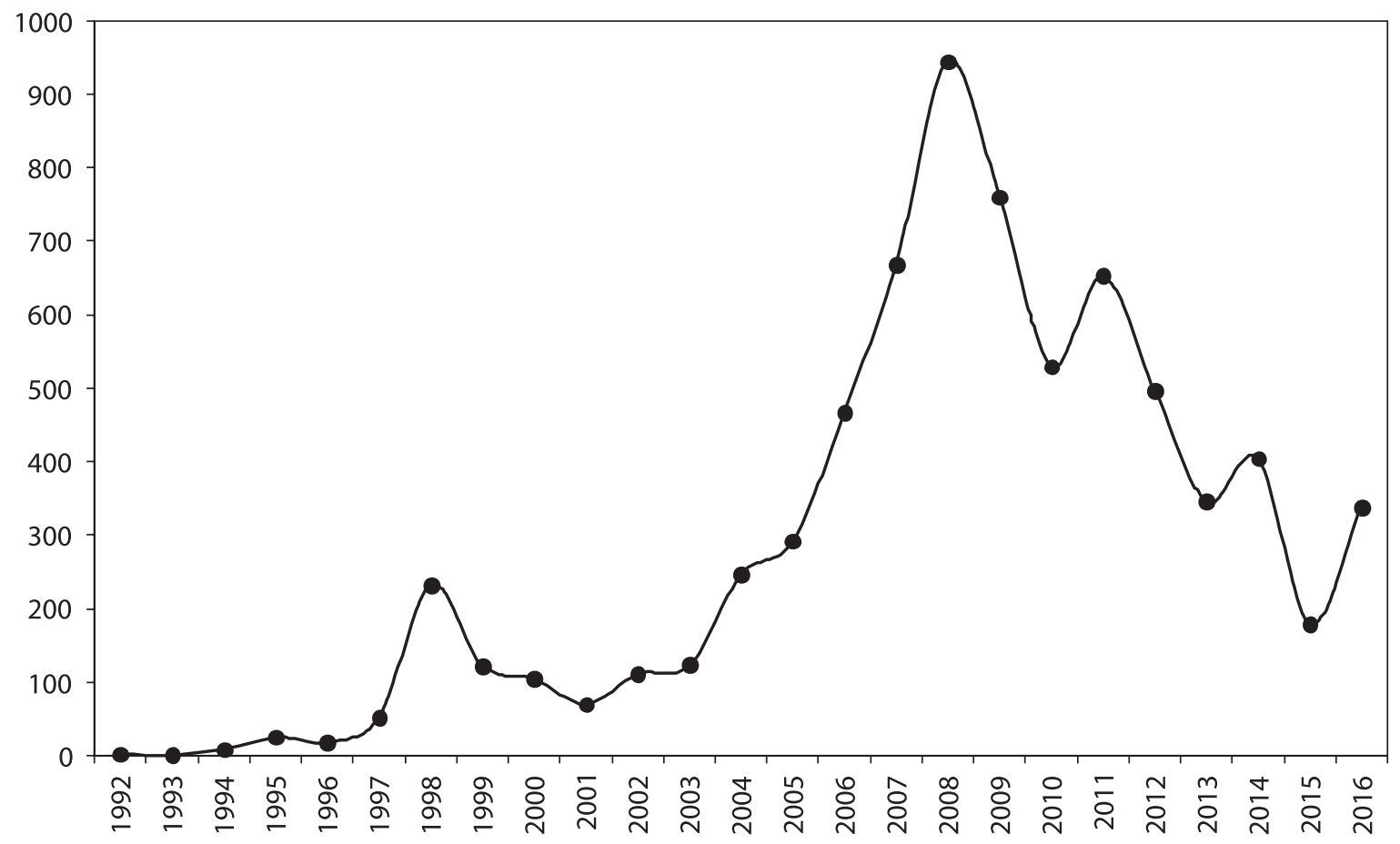

Fig. 1. Inflow of foreign direct investment to Armenia in 1992-2016 [in millions USD]

Source: own elaboration based on UNCTADSTAT data.

sulted in economic growth and subsequent accession to the World Trade Organization (January 2003). A first significant decline in inward flow investment was not observed till after $1998^{\circ}$. A decline in value of foreign investments in Armenia at that time, had its roots in the financial crisis in Russia (1998), which directly affected the economies of its closest allies. After joining the Council of Europe, improving its relations with the European Union and establishing a cooperation with the International Monetary Fund, the World Bank and several national non-governmental organisations, Armenia, for a brief period of time $(2002-2008)^{9}$ regained its political and economic stability which, in turn, contributed to the annual increase of FDI inflows ${ }^{10}$. The effects of Global Financial Crisis (2009), difficult internal situation and political decisions of the authorities make defining a clear trend (an unambiguous decrease or increase) in FDI flows from 2010 onwards, impossible. Political actions directly influencing changes in the FDI value include: (1) decision of president Serzh Sargsyan to suspend any association and trade negotiations with the European Union, (2) joining the Customs

\footnotetext{
8 A decrease from $232 \mathrm{mln}$ USD in 1998 to $122 \mathrm{mln}$ in the following year.

9 In the years 2008-2015, foreign direct investment accounted for an average of $43.6 \%$ of all investments carried out in Armenia in that period.

10 In 2008, the value of FDI inflow was at 944 million USD which was the highest since Armenia had regained its independence in 1991.
}

Union of Russia, Belarus and Kazakhstan (2013), and (3) joining the Eurasian Economic Union, an organisation (referred to, by the Near-East researchers, as an 'economic muzzle') controlled by the Russian Federation, whose main goal is regeneration of strong ties and dependencies from the times of the Soviet Union, and which follows, gaining control over its allies (Ananicz, 2014; Jarosiewicz, Fischer, 2015).

When analysing a foreign direct investment, it is necessary to consider its geographical structure. Directly before the collapse of the USSR and during the first decade after Armenia regained independence, main foreign investors in the region were the Russian Federation, Greece, Canada and the United States (Tab. 2). The situation has changed significantly within the next thirteen years. There has been a significant increase in capital flow from the Russian Federation (more than $40 \%$ of the total FDI) as well as more active participation of other partners (e.g. Argentina and Lebanon). Despite a significant, directional change of FDI flows, the Russian Federation's leading position remains unchallenged. The Russian Federation, has gradually increased its share of the total annual foreign investment in the Armenian economy by $100 \%{ }^{11}$.

It is worth noting that the geographic structure of foreign direct investment in Armenia is affected by the spatial distribution of the Armenian Diaspora,

\footnotetext{
11 More on structure of the Russian investment in Armenia in: Аветисян (2014).
} 
Tab. 2. Armenia's main investment partners in the years 1988-2002 and $2015^{13}$

\begin{tabular}{|l|c|l|c|}
\hline \multicolumn{1}{|c|}{ Foreign Partner } & $\begin{array}{c}\text { Share of country's investment } \\
\text { in the total volume } \\
\text { of FDI inflows (in \%) }\end{array}$ & \multicolumn{1}{c|}{ Foreign Partner } & $\begin{array}{c}\text { Share of country's investment } \\
\text { in the total volume } \\
\text { of FDI inflows (in \%) }\end{array}$ \\
\hline Russian Federation & 21.0 & Russian Federation & 45.2 \\
\hline Greece & 18.7 & Argentina & 5.7 \\
\hline Canada & 12.7 & Lebanon & 5.6 \\
\hline USA & 10.9 & Great Britain & 5.2 \\
\hline France & 7.7 & USA & 5.1 \\
\hline Great Britain & 6.0 & France & 4.7 \\
\hline Luxembourg & 3.3 & Germany & 3.9 \\
\hline Switzerland & 2.5 & Cyprus & 3.7 \\
\hline Cyprus & 2.4 & Switzerland & 3.0 \\
\hline Italy & 1.5 & Netherlands & 2.8 \\
\hline other states & 13.3 & other states & 15.1 \\
\hline
\end{tabular}

Source: own elaboration based on annual publications of National Statistical Service of the Republic of Armenia.
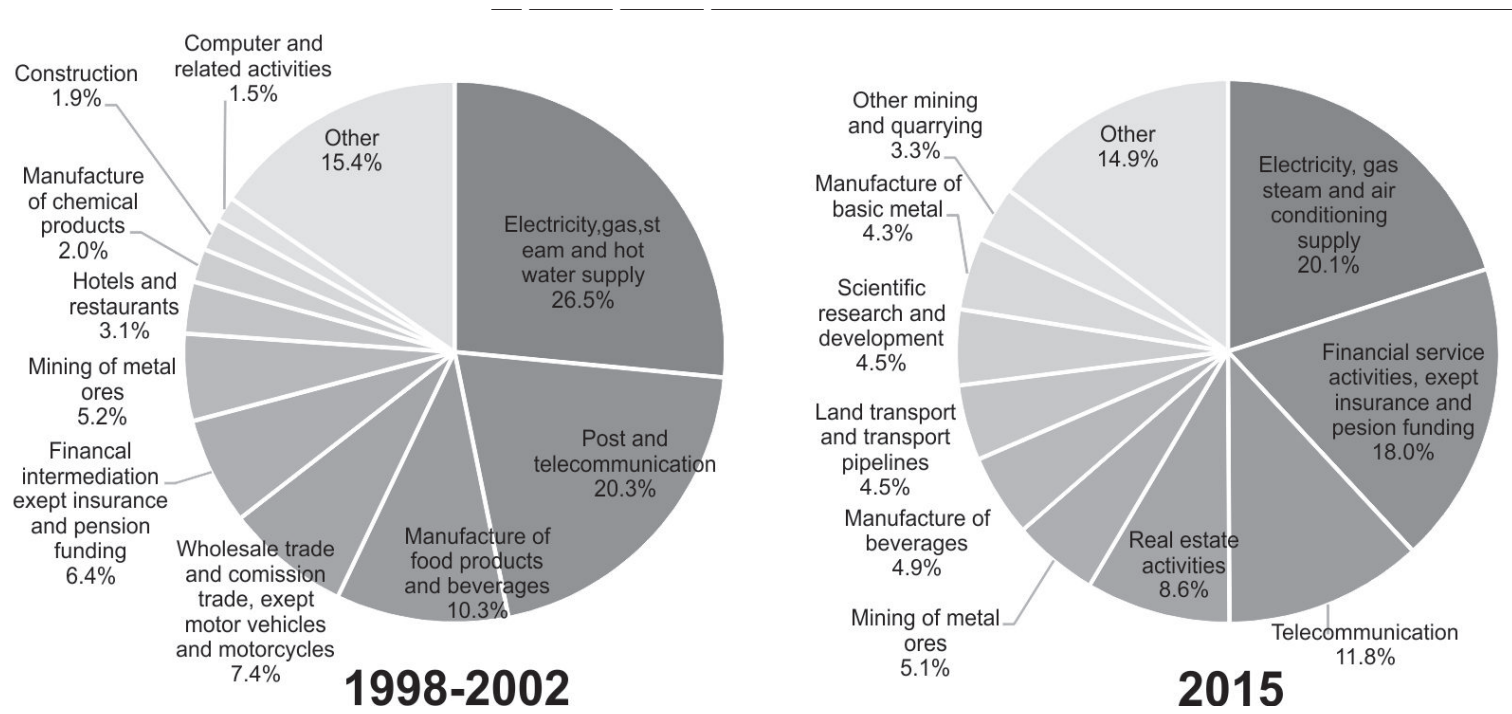

Fig. 2. Sectoral structure of foreign direct investment in Armenia in 1998-2002 and 2015

Source: Own elaboration based on annual reports published by the National Statistical Service of the Republic of Armenia.

whose representatives often choose their homeland as a location of their investment. The estimated number of ethnic Armenians within the world population is over 10 million. Of these, only 2.99 million $^{12}$ live in the Republic of Armenia. The countries with the largest percentage of Armenians are: the Russian Federation, the United States, France, Syria, Lebanon, Argentina, Canada and Iran. This largely

\footnotetext{
12 Estimates calculated by the state authorities based on the results of the last census (2011) Data on the population of Armenia and main clusters of the Armenian Diaspora are available on the website of the President of Armenia.
}

coincides with the ranking of top 10 Armenia's investment partners.

Ownership structure in FDI projects in 1998-2002 indicates private sector companies as most active investors (over $95 \%$ of total FDI). As far as a sectoral structure of FDI inflow in 1998-2002 is concerned, the largest part of the capital was located in the energy sector (31\% of the total), telecommunications (24\%) and food industry (production of food and beverages $-10.3 \%$, Fig. 2 ).

13 Due to the fragmentation of the FDI data, the1988-2002 information relates to grow flows and the 2015 information to net stock. 
Looking at the statistical data from 2015, it is clear that the situation had changed significantly since 2002. On the one hand, the investments by private companies decreased by more than $10 \%$. On the other hand, however, in addition to a still high level of investment in energy (24\%) and telecommunications (14\%), a proportion of investment in financial sector ( $21 \%$ of total investment) and real estate (10\%) increased.

This significant amount of foreign capital within the country's key industries indicates a high degree of dependence on foreign partners. This issue is particularly important when considering the country's energy security as well as economic objectives of the Russian Federation, in relation to countries in its strict sphere of influence. It is worth mentioning that Russia holds a monopoly on gas imports to Armenia till 2024. A good example of the influence exercised over Armenia's energy sector by its northern partner is a gradual takeover of ArmRosGazprom (a joint Russian-Armenian company) by GazRrom (Ananicz, 2014) $)^{14}$.

\section{Conclusion}

After regaining its independence in 1991, Armenia began a process of system transformation. Despite the introduction of numerous reforms related to business liberalisation and privatisation, the country is still struggling with the issue of low level of socioeconomic development, as evidenced by the value of the Bertelsmann Transformation Index. A difficult internal situation is reinforced by the oligarchy based political system, corruption and deepening poverty. From the beginning of the 1990s till today, the volume of FDI inflows to Armenia has changed significantly. The situation was mainly influenced by systemic transformation, political activity of state authorities (especially in regards to the membership of international organisations) and several economic crises (Russian in 1998 and global in 2009). Additionally, the amount of funds flowing into Armenia in the form of FDI was negatively affected by the unresolved armed conflict in Nagorno-Karabakh and subsequent isolation of Armenia within the region (closing of borders by Turkey and Azerbaijan).

The Russian Federation has been Armenia's main investment partner since the 1990s. As far as the in geographic structure of FDI is concerned, the importance of Russian investment in Armenia since the 1990s, has increased by more than $20 \%$. This,

14 http://www.gazprom.com/press/news/2014/january/article182633/ combined with data on the FDI sectoral structure (foreign investment is mainly focused on the key industries of Armenian economy such as energy and telecommunications), indicates a strong dependence on the inflow of Russian capital, which by now is controlling the most strategic state enterprises. The results of statistical examination combined with the information gained from the analysis of political decisions of the Armenian authorities (resignation from EU membership, accession to the Eurasian Economic Union, establishment of Russian military bases on the territory of Armenia), suggest the resuscitation of past political and economic ties and dependencies. Recent events suggest a progressive integration process. This issue is particularly important when looked at from the perspective of the 'Great Game' in the Caucasus, Russia's activity in the region, and maintaining the independence by other post-Soviet republics. The results of the analysis encourage in-depth research on the economic impact of Russia in the Caucasus region.

\section{References}

Ananicz Sz., 2014, Armenia na drodze do Unii Celnej (i większego uzależnienia od Rosji), Ośrodek Studiów Wschodnich im. Marka Karpia, Warszawa [15.04.2017].

Armenia Country Report BTI 2016, 2016, Bertelsmann Stiftung, Gütersloh, https://www.bti-project.org/fileadmin/files/ BTI/Downloads/Reports/2016/pdf/BTI_2016_Armenia. pdf, [18.04.2017].

ARMSTAT - National Statistical Service of the Republic of Armenia, Yerevan, http://www.armstat.am/en/ [16.04.2017].

Bartlett D.L, 2000, Stabilization Policy in Post-Soviet Armenia, Post-Soviet Geography and Economics, 41 (1), 30-47.

Bojar E., 2001, Bezpośrednie inwestycje zagraniczne w obszarach słabo rozwiniętych, Wydawnictwo Naukowe PWN, Warszawa.

Cohen A., 1996, The New "Great Game": Oil Politics in the Caucasus and Central Asia, The Heritage Foundation, http:// www.heritage.org/europe/report/the-new-great-gameoil-politics-the-caucasus-and-central-asia [15.04.2017].

Falkowski M., 2015, Protesty w Armenii jako przejaw systemowego kryzysu państwa, Ośrodek Studiów Wschodnich im. Marka Karpia, Warszawa, https://www.osw.waw.pl/pl/ publikacje/analizy/2015-07-01/protesty-w-armenii-jakoprzejaw-systemowego-kryzysu-panstwa [15.04.2017].

Gazprom, http://www.gazprom.com/press/news/2014/january/article182633/ [16.04.2017].

Gołaś K., 2011, Region Kaukazu w polityce Federacji Rosyjskiej - wybrane aspekty, Przegląd Geopolityczny, 3, 109-123.

Invest in Armenia. Global SPC, Yerevan, http://investinarmenia.am/en/investment-incentives [18.04.2017].

Iwańczuk K., 2008, Geopolityka Kaukazu, [in:] K. Iwańczuk, T. Kapuśniak (eds.), Region Kaukazu w stosunkach między- 
narodowych, Wydawnictwo Uniwersytetu Marii Curie-Skłodowskiej, Lublin, 15-19.

Jarosiewicz A., 2017, Wybory w Armenii - brzemię zwycięstwa partii rządzącej, Ośrodek Studiów Wschodnich im. Marka Karpia, Warszawa [18.04.2017].

Jarosiewicz A., Fischer E., 2015, Eurazjatycka Unia Gospodarcza - więcej polityki, mniej gospodarki, Ośrodek Studiów Wschodnich im. Marka Karpia, Warszawa [15.04.2017].

Loda Ch., 2017, The European Union as a normative power: the case of Armenia, East European Politics, 33(2), 275290.

Ministry of Foreign Affairs of the Republic of Armenia, Yerevan, http://www.mfa.am/en/international-organisations/ [18.04.2017].

Odling-Smith J., 2001, The Economic Transition in Armenia (speech), International Monetary Fund, https://www. imf.org/en/News/Articles/2015/09/28/04/53/sp073101 [15.04.2017].

President of the Republic of Armenia, Yerevan, http://www. president.am/en/diaspora/ [16.04.2017].

Sadowski R., 2013, Szczyt w Wilnie: bez przełomu w Partnerstwie Wschodnim, Ośrodek Studiów Wschodnich im. Marka Karpia, Warszawa, https://www.osw.waw.pl/pl/publikacje/ analizy/2013-12-04/szczyt-w-wilnie-bez-przelomu-wpartnerstwie-wschodnim [15.04.2017].

Transformation Index BTI 2016, Bertelsmann Stiftung, Gütersloh, https://www.bti-project.org/en/index/status-index/ [18.04.2017].

UNCTADSTAT, United Nations Conference on Trade and Development, Geneva, http://unctadstat.unctad.org/wds/ TableViewer/tableView.aspx [16.04.2017].

Аветисян А.О., 2014, Российские Прямые Инвестиции в Армении, МИР (Модернизация. Инновации. Развитие), 3(19), 93-95.

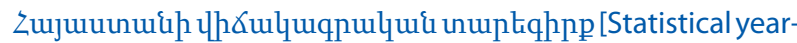
book of Armenia], 2016, ¿之 Uqqujh\{ प,hðulquqpulqui Ounujnıрjnı\{, Epluwi.

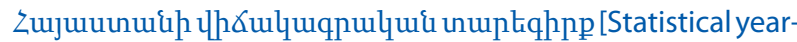

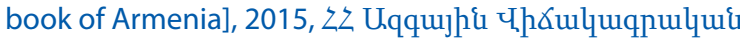
Ounujnıpjnı\{, Łpluui.

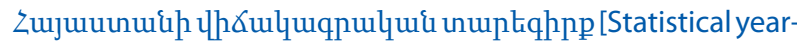

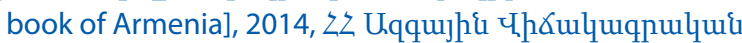
Ounujnıрjnı\{, Epluuis.

Zujuuunuip th6ulquqnulyuí unuptiqhpp [Statistical year-

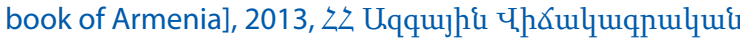
Ounujnıpjnı\&, Epluwi.

Zujuuunu\{h 내 Xulquqnulqui unuptiqhpp [Statistical yearbook of Armenia], 2012, ¿之 Uqqujh\{ પ, hชulquqpulqui Ounujnıpjnı\{, Epliuiq.

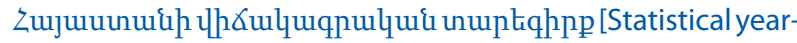

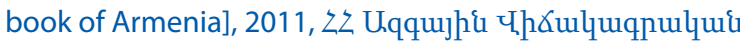
Ounujnıpjnı\{, Ephuuq.

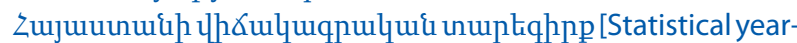

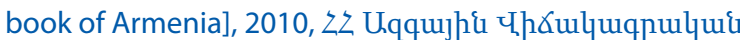
Ounujnıpjnıq, Epluwi.

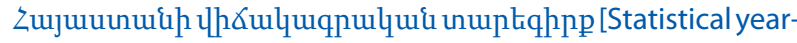

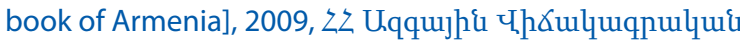
Ounujnıpjnı\&, Epluui.

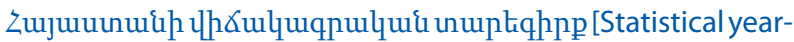

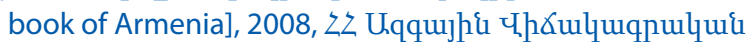
Ounujnıpjnı\{, Epluui.

¿之 Optipn Ounupknlpju しtipnpnuরutiph Uuuhd [On Foreign Investment], 1994, ¿zQTuS 1994/14, ¿O-115, http:// www.arlis.am/ [16.04.2017]. 